\title{
Kalitede Yeni Bir Sayfa mı Yoksa Eskilerin Tekrarı mı? Bazı Devlet Üniversitelerinin Kurumsal İç Değerlendirme Raporlarının Eğitim Perspektifi
}

\author{
Eda Atatekin ${ }^{1 *}$, Murat Ali Dulupçu² \\ 'Süleyman Demirel Üniversitesi, Öğretim Görevlisi. ${ }^{2}$ Süleyman Demirel Üniversitesi Iktisadi ve Idari Bilimler Fakültesi, Iktisat Bölümü Öğretim Üyesi,
}

\begin{abstract}
Özet
Yükseköğretim alanında kalite ile ilgili çalışmalar 1990'lardan sonra hız kazanmıştır. Mevzuat düzenlemeleri ile önce Yükseköğretim Kurumlarında Akademik Değerlendirme ve Kalite Değerlendirme Komisyonu sonra Akademik Değerlendirme Komisyonu kurulmuş olsa da bu alandaki radikal düzenleme, 2015 yılındaki kalite yönetmeliği ile üniversitelerin kendi iç değerlendirmelerini yapmalarının ve dış değerlendirmeye tabii olmalarının zorunlu bir süreç haline gelmesidir. Kaldı ki yönetmelik hükümleri diğer bir ifade ile Yükseköğretim Kalite Güvencesi Sistemi ve Yükseköğretim Kalite Kurulu, 2017 yılında Resmi Gazete'de yayımlanan 30111 sayılı kanun ile yasalaşmıştır. Bu çalışma, Türkiye'de 1992 yılında kurulan beș devlet üniversitesinin kurumsal iç değerlendirme raporlarını eğitim boyutunda karşılaștırmalı olarak içerik analizi ile değerlendirmektedir. Bu kapsamda; iç ve dış paydaşların sürece katılımı, öğretim elemanlarının performansı, özel yaklaşım gerektiren öğrencilere yönelik hizmetler, öğrenci oryantasyon programları, öğrenme kaynaklarının zenginliği, öğrencilere yönelik kariyer geliştirme hizmetleri, öğrenci memnuniyeti ve mezun izleme sistemleri açısından karşılaştırma yapılmış ve sonuçlar paylaşılmıștır.
\end{abstract}

Anahtar Kelimeler: Yükseköğretimde kalite, kurumsal iç değerlendirme, üniversite

\section{A New Chapter or a Repetition of the Past in Quality? The Education Perspective of the Internal Institutional Evaluation Reports of the Selected State Universities}

\begin{abstract}
The studies about quality in the field of higher education has started to accelerate since the 1990s. Even though initially Academic and Quality Evaluation Commissions at Higher Education Institutions and afterwards Academic Evaluation Commissions have been founded with legislative arrangements, the most radical arrangement has been introduced with the quality regulation in 2015, making the internal evaluations at universities, as well as subjection of external evaluations obligatory procedures. Moreover, the legislative regulations, in other words Higher Education Quality Assurance System and Higher Education Quality Council have been passed into law in 2017, and they have been published at the official gazette with law number 30111. This work, evaluates the internal institutional evaluation reports of five Turkish state universities founded in 1992 comparatively, from the standpoint of educational format with content analysis. In this context, the contribution of internal and external partners to the procedure, the performance of the faculty members, the services addressed to the students requiring special treatment, the student orientation programs, redundance of learning sources, career development services aimed for students, satisfaction of the students, and alumni surveillance systems have been taken into consideration for comparison, and the results have been revealed.
\end{abstract}

Keywords: Quality in higher education, institutional internal evaluation, university

\section{Giriș}

Kalite, uzun yıllar boyunca, ürüne, süreçlere, işe ve insana eklemlenmiş bir sorunun cevabı olarak literatürde yerini almış ve birçok tanımlamaya sahip olmuştur. Kalite anlayışı değişen sistemlere, düzenlere, yapılara bağlı olarak değişiklik göstermiştir.

*Yazışma Adresi / Address for Correspondence:
Eda Atatekin, Email: edaatatekin@hotmail.com
Geliş Tarihi / Received Date: 13.02 .2018
Kabul Tarihi / Accepted Date: 25.03 .2018
Doi: $10.26701 /$ uad.394020

Bilgi toplumunun önem kazanması ile üniversiteler eğitim, araştırma fonksiyonlarına bilginin üretilmesini, yayılmasını, aktarılmasını eklemiş ve toplumun ihtiyaçlarına cevap verebilen kurumlar haline gelmişlerdir. Bunun sonucu olarak yükseköğretim kurumlarından beklentiler artmış ve paydaşlarına karşı sorumlulukları artan yükseköğretim kurumlarının hizmetlerinin sorgulanması, hesap verebilir hale gelmesi sağlanmıştır. Yükseköğretim hizmetlerinin kaliteli olması, üzerinde uzlaşıya varılmış bir konu olmasına rağmen bu kalitenin nasıl sağlanacağı, korunacağı, geliştirileceği ve güvence altına alınacağı hu- 
suslarında çalıșmalar devam etmektedir.

Öğrenciler yükseköğretim sistemi içinde yer alan ve bu sistemin hizmetlerinden faydalanan en önemli paydaşlardır. Öğrencilerin 1980’li yıllardan itibaren değerlendirme süreçlerinde önemli bir geri bildirim noktası olduğu bilinmektedir. Avrupa Birliği, öğrenci merkezli yükseköğretim politikalarına sahiptir ve Bologna süreci ile yükseköğretim kurumlarının rekabet gücünün artırılması hedeflenmiştir. Bu rekabetin bir sonucu olarak kalite güvencesi konusu önem kazanmış; ortak anlayış ve değerlere dayalı Avrupa ilke ve standartları ile uyumlu kalite güvence sistemi oluşturma çabaları başlamıştır. Öğrencilerin eğitim-öğretim sürecinde elde ettiği öğrenme kazanımları Bologna sürecinin getirdiği en önemli yeniliktir. Türkiye, 2001 yılında Bologna sürecine katılmış; Akademik Değerlendirme Komisyonu (ADEK) ve Bologna Eşgüdüm Komisyonu (BEK) raporlarında öğrencilerle ilgili bilgi ve değerlendirmeler yer almıştır. 2005 yılında "Yükseköğretim Kurumları Öğrenci Konseyleri” ve "Yükseköğretim Kurumları Ulusal Öğrenci Konseyi Yönetmeliği” ile öğrencilerin, yükseköğretim kurumlarındaki karar ve uygulama süreçlerine katılımının desteklenmesi resmiyet kazanmıştır. Daha radikal bir adım olarak nitelendirilebilecek olan "Yükseköğretim Kalite Güvencesi Yönetmeliği” 2015 yılında yürürlüğe girmiş ve bu yönetmelik çerçevesinde yükseköğretim kurumları bünyesinde oluşturulan kalite komisyonlarında öğrencilere de yer verilmiştir. 2017 yılında 30111 sayılı Resmi Gazete'de yayımlanan 7033 Sayılı "Sanayinin Geliştirilmesi ve Üretimin Desteklenmesi Amacıyla Bazı Kanun ve Kanun Hükmünde Kararnamelerde Değişiklik Yapılmasına Dair Kanun'un Ek 35. maddesinde Yükseköğretim Kalite Güvence Sistemi ve Yükseköğretim Kalite Kurulu hakkında düzenleme yapılmıştır. Üniversitelerin kalite açısından iç ve dış değerlendirmeye tabii olması yasalaşmıştır.

Bologna sürecinin temel hedeflerinden biri olan yükseköğretimde kalite güvencesi sistemleri ağını oluşturmak ve yaygınlaştırmak eylemine yönelik çalışmalar, günümüzde, yükseköğretim alanının en önemli gündem maddesini oluşturmaktadır. Bologna sürecinde yükseköğretim kurumlarının kalitesinin yükseltilmesi ve ortak kabul görmüş belirli standartlarla yükseköğretimde kalite güvence sistemlerinin oluşturulmasına yönelik yapılan çalışmalar kapsamında Avrupa Yükseköğretimde Kalite Güvencesi Kaydı (European Quality Assurance Register for Higher Education- EQAR) tarafindan 2005 yılında Avrupa Yükseköğretim Alanı'nda Kalite Güvence Standartları ve Yönergeleri yayınlanmıştır. Bu yönerge, kalite çalışmalarına rehberlik etmekte ve bu sayede Avrupa Yükseköğretim Alanı'nda, yükseköğretim kurumlarının birbirleri ile uyum içinde ve kıyaslanabilir kalite düzeyinde hizmet vermelerini hedeflemektedir ${ }^{1}$.

Avrupa Yükseköğretim Alanı ve Avrupa Araştırma Alanı oluşturulmasını hedefleyen Sorbonne Bildirisi'nin imzalanmasının ardından, 1999 yılında 29 Avrupa ülkesinin yükseköğretimden sorumlu bakanlarının imzaladığı Bologna Bildirisi ile Bologna süreci resmi olarak başlamıştır. Türkiye, Bologna sürecine 2001 yılında Prag'da dahil olmuştur. Böylece, Bologna sürecinin gerektirdiği faaliyetler ülkemiz yükseköğretim sisteminde de uygulanmaya başlanmış ve aynı zamanda süreçle birlikte kalite güvencesi konusu ülkemizde en çok tartışılan konulardan biri olmuştur (Çelik, 2012).

Kurumsal Değerlendirme Programı 1994 yılından bu yana dünyada yükseköğretim kurumlarının talebi üzerine Avrupa yükseköğretim liderlerinden oluşan dış değerlendirme takımı ile yükseköğretim kurumlarına dış değerlendirme hizmeti vermektedir. Kurumsal Değerlendirme Programı, bir bütün olarak kurumu ele almaktadır (EUA, 2005, s. 2). Değerlendirme metodolojisinde yer alan sorular, yükseköğretim kurumlarının kendilerini analiz etmesine olanak sağlamaktadır. Kurumsal değerlendirme raporları, yükseköğretim kurumlarının gelişimine yöneliktir ve kalitenin geliștirilmesi ve kalite konusunda iyileştirmelerin yapılabilmesi için önerilerde bulunmaktadır (EUA, 2010, s. 6).

Uluslararasılaşmanın önem kazanmasıyla birlikte verilen eğitim programlarının, diplomaların karşılaştırılabilir olması için bilgi, beceri ve yetkinliğin bütününü ifade eden öğrenme kazanımlarının belirlenmesi gerekmektedir. Ülkemizde de Yükseköğretim Yeterlilikler Çalışması başlatılmış, Türkiye Yükseköğretim Yeterlilikler Çerçevesi (TYYÇ) hazırlanmıştır. TYYÇ kapsamında temel alan yeterlilikleri belirlenmiş, bu yeterlilikler çerçevesinde yükseköğretim kurumları tarafından ders kredileri ve öğrencinin iş yükünün belirlenmesiyle yükseköğretim kurumları arasındaki farklılıkların öğrenme ortamında oluşturacağı engellerin ortadan kaldırılması, ilgili kanun maddesinde değişikliği gerekli kılmıştır. Bu değişiklikle beraber yükseköğretim kurumları TYYÇ ve temel alan yeterlilikleri ile uyumlu program yeterliliklerini belirlemekte ve ilgili programda verilecek dersler için ders bilgi paketleri hazırlanmaktadır.

Çağımızda yaşanan dijital devrimle birlikte eğitim de dijitalleşmeye başlamış ve kullanılan teknolojiler nedeniyle eğitim kalitesi daha önemli hale gelmiştir. Bu nedenle eğitim olanaklarının yeni sistemler çerçevesinde revize edilmesi gereği ortaya çıkmıştır.

Yükseköğretim alanında kalite konusunun Türkiye'nin gündemine gelmesi tesadüfi değildir. Özellikle iki temel argüman bu süreci şekillendirmiştir. Birincisi uluslararası çeşitli sıralamalar açısından rekabetçi bir ekonomik yapı için şart kabul edilen ve üniversiteler ile ilişkisi de yoğun olan göstergelerde Türkiye'nin konumunun iyileştirilmesi üzerinde politik ve toplumsal konsensüstür. En basit hali ile Ar-Ge harcamalarının milli gelirdeki payından başlayan bu alan uzun vadeli ekonomik başarının anahtarı kabul edilmektedir. İkincisi Türkiye'de üniversitelere olan taleptir. Bu talep halkın geleneksel yüksek "okuma” beklentileri ve işgücü piyasasının mesleki eğitimde göreli ye- 
tersiz düzenlenmesi ile tarihsel olarak yüksek seyretmektedir. Elbette genç nüfus yapısı söz konusu talebin başat nedenidir. Bu yüksek talebe 2000'lerden sonra yükselen arz ile yani artan üniversite sayı ve kontenjanları ile karşılık verilmesi nicelin yanında nitel olanın da düşünülmesi ve geliştirilmesi gerekliliğini ortaya çıkarmıştır.

2015 yllında yönetmelikle, 2017'de ise yasa ile üniversitelerin kurumsal iç değerlendirme raporları (KIDR) hazırlamaları bir zorunluluk halini almıștır. Stratejik plan, faaliyet raporları, BEK, YÖDEK raporları gibi bir süreçten sonra KIDR yeni bir sayfa açma iddiasında görülmektedir. Kurumsal iç değerlendirme raporları incelendiğinde kalite güvencesi, eğitim-öğretim, araştırma ve geliştirme, yönetim sistemi olmak üzere dört ana bölümden oluştuğu görülmektedir. İlk raporlar önceki birikimlerden etkilense de kompleks yapısı zamanla profesyonel kalite anlayışını yansıtacak bir içeriğe sahiptir. Daha da önemlisi üniversitelerin artan nicelikleri karşısında nitel rekabetini şekillendirmede yardımcı bir rehber özelliğini de taşımaktadır.

Bu çalışmada, ülkemizde 1992 yılında kurulan üniversiteler arasından beș üniversite seçilerek incelenmiştir. ${ }^{2}$ Çalışma dünya ve Türkiye'deki yükseköğretim kalite süreçlerini inceledikten sonra seçilmiş üniversitelerdeki KIDR raporlarının eğitim perspektifinden içeriğini değerlendirmeyi hedeflemektedir.

\section{DÜNYADA YÜKSEKÖĞRETIMDE KALITE GÜVENCE SISTEMI}

II. Dünya Savaşı'ndan sonra sanayi toplumu yerini bilgi toplumuna bırakmış ve bilgiye dayalı ekonominin önemi artmaya başlamıștır. Sanayi toplumunda ön planda olan üretim faktörleri, bilgi yoluyla üretilmeye başlanmıştır. Teknolojinin gelişimi bilgiyi üreten ve kullanan insan gücü ile bu gücü sağlayacak eğitimin sürekli olmasını önemli hale getirmiștir. Aynı zamanda, küreselleşmenin neden olduğu yapısal değişimler nitelikli insan ihtiyacını ortaya çıkarmıştır (Aktan ve Tunç, 1999).

Küresel ekonomik yapının bilgi ekonomisini doğurması, ülkelerin rekabet gücünün beşerî sermayenin kalitesi ile ölçülebilen bir hal almasını sağlamıştır (YÖK, 2007, s. 13). Bu değişim yükseköğretimi etkilemiş, sürekli kendini yenileyen bilgi ihtiyacı karşısında yükseköğretim alanında gelişmeler yaşanmaya başlanmıştır. Eğitimli insan gücünün artmasıyla yükseköğretime katılım oranı önce Amerika'da daha sonra Avrupa'da ve sonrasında gelişmekte olan ülkelerde artış göstermiştir.

1950 'li yıllar boyunca ve 1960 'lı yılların başında sanayi ve ticaret sektörlerinde kalite güvencesi yönetimi başl1ca metodoloji olarak ortaya çıkmıştır. 1980'li yılların ortasında birçok Ekonomik Kalkınma ve İşbirliği Örgütü (OECD) ülkesinde kamu kaynaklarının kullanımı ve da-

22008 yılından itibaren bütçesi 100 milyon liranın üzerinde seyreden ve toplam öğrenci sayısı 20 binin üzerinde olan Adnan Menderes (ADÜ), Kocaeli (Kocaeli), Sakarya (SAÜ), Süleyman Demirel (SDÜ), Pamukkale (PAÜ) üniversiteleri örneklem olarak seçilmiştir ğıtımında hesap verilebilirliğin ve etkinliğin geliştirilmesi için kamu sektörüne Toplam Kalite Yönetimi anlayışı, yükseköğretimde ise Kalite Güvencesi yerleşmeye başlamıştır (Fang, 2010).

Yükseköğretim sisteminin genişlemesi, farklı eğitim yöntemlerinin kullanılması, heterojen yapıdaki öğrencilerin ihtiyaç ve taleplerine karşlık verebilme amacı, yükseköğretime ayrılan kamu fonlarının azalması, kullanılan kamu fonlarının etkinliğinin sorgulanması, iç ve dış paydaşların ihtiyaçlarını göz önünde bulunduran yükseköğretim sistemlerinde rekabetçi bir yapının ortaya çııı̧ı ve diğer taraftan yükseköğretimde hareketlilikle beraber uluslararasılaşmanın öneminin artması kalite teminini gerekli kılmıştır (Bakioğlu ve Baltacı, 2010).

Birleşmiş Milletler Eğitim, Bilim ve Kültür Örgütü (UNESCO)'nün 1998 yılında yükseköğretimle ilgili aldığı kararlarda, kalite, üzerinde önemle durulan konulardan biri olmuştur. Kurumlar için iç ve dış değerlendirmenin önemi üzerinde durulmuş, kalite standartlarının oluşturulması ve bu standartlar oluşturulurken ulusal, bölgesel, kurumsal özelliklerin önemli olduğu, öğretim elemanlarının seçimine, eğitim-öğretim yöntemlerine önem verilmesinin gerekliliği ve bilgi teknolojilerinin kalite çalışmalarında önemli bir araç olduğu vurgulanmış, kalitenin uluslararası boyutunun ihmal edilmemesi gerektiği belirtilmiştir (Rehber, 2007).

Yükseköğretim kurumlarını kalite güvencesi bakımından değerlendirmek için temel araç akreditasyondur. Akreditasyonla birlikte yükseköğretim kurumları; öğretim elemanı profillerine, müfredatlarına, öğrenci ve kütüphane hizmetleri gibi temel eğitim bileșenlerine göre incelenmekte ve bu kurumların asgari standartları sağlayıp sağlamadıklarına bakılmaktadır. Akreditasyon, ilk olarak 20. yüzyıl başında Amerika Birleşik Devletleri (ABD)'nde yükseköğretime olan talepteki artış ve yeni çalışma alanlarının ortaya çıkmasının sonucu başlamıştır ${ }^{3}$.

Tablo 1: ABD'de Yıllara Göre Akreditasyon Gelişimi

\begin{tabular}{|c|c|}
\hline Yıl & Akreditasyon Kapsamında Gerçekleştirilenler \\
\hline 1885 & İlk bölgesel akreditasyon ajansının kurulması \\
\hline 1907 & İlk ihtisaslaşmış akreditasyon ajansının tıp alanında açılması \\
\hline 1910 & İlk akreditasyonun yapılması \\
\hline 1932 & Mühendislik programlarının akreditasyon sürecinin başlaması \\
\hline 1938 & $\begin{array}{l}\text { Eyalet Üniversiteleri Ulusal Birliği, Land Grant Kolejleri Birliği ve } \\
\text { Amerikan Üniversiteleri Birliği'nden oluşan ortak bir komitenin } \\
\text { oluşturulması }\end{array}$ \\
\hline 1949 & Ulusal akreditasyon komitesinin kurulması \\
\hline 1974 & $\begin{array}{l}\text { Ulusal Akreditasyon Komitesi ile Yükseköğretim Kurumları Böl- } \\
\text { gesel Akreditasyon Komisyonları Birliği'nin birleşerek Lise Sonrası } \\
\text { Akreditasyon Kurulu’na dönüşmesi }\end{array}$ \\
\hline
\end{tabular}

Kaynak: Kısakürek, 2007 s.10; Bakioğlu, ve Baltacı, 2010 s.43; Rehber, 2007 s.232. ABD'de kalite güvencesi ve akreditasyon yapısı yükseköğretime benzer şekilde âdem-i merkeziyetçi ve karmaşı bir düzene sahiptir (Özer vd., 2010). Kalite güvencesinden tek bir kuruluş sorumlu olmamakla beraber hükümet

3 ABD'de akreditasyonla ilgili çatı kuruluşlar Council on Higher Education Accreditation (CHEA) ve United States of Department Education (USDE)'dir (Bakioğlu ve Baltacı, 2010 s.44). 
bu süreçte sınırlı ve dolaylı bir role sahiptir (Aydınalp, 2011). Akreditasyon, özel olan ve kâr amacı gütmeyen farklı standartlardaki kurumlar tarafından yürütüldüğü için yükseköğretimin dış kalite değerlendirmesi, temelde devlet dışı kurumlar tarafından yürütülmektedir (Özer vd., 2010).

ABD'de; bölgesel, ulusal ve merkezi olmak üzere üç tür akreditasyon yapısı ile kurumsal akreditasyon ve program akreditasyonu olmak üzere iki tür akreditasyon bulunmaktadır (Kısakürek, 2007). Bölgesel akreditasyon kuruluşları belirlenen coğrafi alanlarda akreditasyonu gerçekleştirmekte ve kurumsal kaliteye odaklanmakta iken, ulusal akreditasyon kurumları, belirli alanlarda ders veren kurumların, uzaktan eğitim veren kolej ve üniversiteler ile dini temelli vakıf okullarının akreditasyonuna odaklanmaktadır. Mesleki akreditasyon kurumları da tek bir programin akreditasyonundan sorumludurlar (Dickey ve Miller, 1972). Kurumsal akreditasyonda yükseköğretim kurumunun bir bütün olarak değerlendirilmesine odaklanılmakta ve kurum bir bütün olarak akredite edilmektedir. Program akreditasyonu ise sadece bir bölüme/ derse/eğitim programına odaklanmakta ve program temelli faaliyetlere yönelmektedir (Koenig vd., 2004); (Aktan ve Gencel, 2007).

1960’lı ve 1970'li yıllarda Avrupa'da nüfus büyüklüğü fazla olan Fransa, Almanya, İngiltere gibi ülkelerde çok sayıda üniversite kurulmuştur. Yükseköğretim kurumlarının sayılarında ve okullaşma oranında yaşanan artışlar sonucu yükseköğretimde büyüme ve çeşitlenme sağlanmış, kalite konusu yükseköğretimin gündeminde yerini almaya başlamıștır (Özer vd., 2010).

1984 yllında İngiltere'de kalitenin yükseköğretimin ana hedeflerinden biri olduğu beyan edilmiş, 1985 yllında Fransa'da Comitg National d'Evaluation kurulmuştur. İzleyen ylllarda Danimarka, İspanya, Hollanda gibi çeşitli ülkeler kalite değerlendirme sistemi ile ilgili ilk adımlarını atmışlardır (Vught vd., 1994).

1984 yllında üniversitelerin değerlendirmesini yapan Avrupa'daki ilk örnek Fransa'dır. 1990'lı yllarda ise Finlandiya'da kurum değerlendirilmesi; Danimarka, Hollanda ve İngiltere gibi ülkelerde program değerlendirilmesi ile ilgili çalışmalar yapılmıştır (Süngü ve Bayrakçı, 2010 s.912). Avrupa'da yükseköğretim sistemlerindeki çeşitlilik ve yükseköğretimdeki genişleme, öğrenci sayılarındaki hızlı artışla birlikte ortaya çıkan çalışma alanlarının sayısının artması, yükseköğretim kurumlarının maliyetleri, bütçe kesintileri yükseköğretim kalite sürecinin sorgulanmasına neden olmuştur (Vught vd., 1994). Avrupa'daki kalite çalışmaları Bologna süreci ile birlikte hız kazanmıștır.

Bologna sürecinin amaçlarından biri olan kalite güvencesi ile ilgili Avrupa'da kalite güvencesinde işbirliklerinin oluşturulması, akreditasyonlarla ilgili sorunların ortaya konması, mevcut akreditasyon modellerinin tartışılması ile ilgili çalışmalar yapılmıştır (Sebkova, 2002).
Tablo 2: Bologna Süreci

\begin{tabular}{|c|c|c|}
\hline $\bar{\Sigma}$ & Olay & Hedefler \\
\hline$\stackrel{\check{\Omega}}{\sigma}$ & $\begin{array}{l}\text { Lizbon } \\
\text { Tanıma } \\
\text { Konvansi- } \\
\text { yonu }\end{array}$ & $\begin{array}{l}\text { Avrupa Konseyi ve UNESCO tarafından Avrupa'nın } \\
\text { dünyadaki tek blok halinde bilgi tabanlı ekonomik } \\
\text { güç olma yolunda rekabet etmeyi hedeflemesi üzeri- } \\
\text { ne hazırlanmıştır. }\end{array}$ \\
\hline ฉ̊ & $\begin{array}{l}\text { Serbonne } \\
\text { Deklaras- } \\
\text { yonu }\end{array}$ & $\begin{array}{l}\text { Almanya, İtalya, İngiltere, Fransa eğitim bakanları } \\
\text { tarafından imzalanmış; ortak yeterlilikler çerçevesi } \\
\text { oluşturulması, akademik derecelerin tanınmasının ge- } \\
\text { liştirilmesi, diploma eki verilmesi, öğrenci ve öğretim } \\
\text { elemanı hareketliliği önündeki engellerin kaldırılması, } \\
\text { Avrupa işgücü piyasasına entegrasyonun sağlanması, } \\
\text { uluslar arası karşılaştırılabilirlik ve denklik için lisans } \\
\text { ve lisansüstü öğrencilerine ortak bir derece sisteminin } \\
\text { oluşturulması ve bu sitemin yaygınlaştırılması }\end{array}$ \\
\hline Д & $\begin{array}{l}\text { Bologna } \\
\text { Deklaras- } \\
\text { yonu }\end{array}$ & $\begin{array}{l}\text { Birbiriyle karşılaştırılabilir yükseköğretim dereceleri } \\
\text { oluşturmak, bu karşılaştırmanın yapılabilmesi için alınan } \\
\text { eğitimin içeriğini düzenleyen diploma ekinin verilmesi, lisans } \\
\text { öğrencileri ve lisansüstü öğrenciler için iki basamaklı ortak } \\
\text { bir derece sisteminin oluşturulması, Avrupa Kredi Transfer } \\
\text { Sistemi'nin uygulanması ve benimsenmesi, öğrencilerin ve } \\
\text { öğretim elemanlarının hareketliliğinin sağlanması, yükseköğ- } \\
\text { retimde kalite güvence sistemleri ağının oluşturulması ve } \\
\text { yaygınlaştırılması ve yükseköğretimde Avrupa boyutunun } \\
\text { geliştirilmesi }\end{array}$ \\
\hline চ্ণ & $\begin{array}{c}\text { Prag } \\
\text { Toplantısı }\end{array}$ & $\begin{array}{l}\text { Bologna sürecinde belirlenen altı eylem başlığına } \\
\text { yaşam boyu eğitimin geliştirilmesi, Avrupa Yükseköğ- } \\
\text { retim Alanı'nın oluşturulmasında öğrencilerin etkin } \\
\text { katılımının sağlanması, uluslararası eğitimin geliştiril- } \\
\text { mesi için işbirliklerinin yapılması }\end{array}$ \\
\hline ปి & $\begin{array}{c}\text { Bratislavya } \\
\text { Deklaras- } \\
\text { yonu }\end{array}$ & $\begin{array}{l}\text { Eğitimde bilgi ve iletişim teknolojilerinin kullanımının } \\
\text { yaygınlaşması, öğretmen eğitimi, temel becerilerin } \\
\text { geliştirilmesi, yabancı dil konusu, hayat boyu öğren- } \\
\text { menin desteklenmesi, eğitim sistemlerinin bireyle- } \\
\text { rin kişisel becerilerinin geliştirilebilmesine olanak } \\
\text { sağlayacak şekilde esnek olması, Avrupa yükseköğ- } \\
\text { retim sisteminde yer alan kurumların yerel ve ulusal } \\
\text { konulara duyarlı kalite güvence sistemleri içinde } \\
\text { değerlendirmesinin yapılabilmesi için kalite güvence } \\
\text { sistemlerinin geliştirilmesi }\end{array}$ \\
\hline ஜ̊̊ & $\begin{array}{c}\text { Berlin } \\
\text { Konferansı }\end{array}$ & $\begin{array}{l}\text { Sorbonne, Bologna ve Prag'da belirlenen dokuz eylem } \\
\text { başlığına ek olarak eğitim programlarının lisans, } \\
\text { yüksek lisans ve doktora şeklinde derecelendirilmesi, } \\
\text { doktora programlarının Avrupa Yükseköğretim Alanı } \\
\text { ile Avrupa Araştırma Alanı arasındaki bağı oluşturma- } \\
\text { sı ve bu kapsamda doktora öğrencilerinin hareketlili- } \\
\text { ğinin artırılması }\end{array}$ \\
\hline ஜ̊ & $\begin{array}{c}\text { Bergen } \\
\text { Kongresi }\end{array}$ & $\begin{array}{l}\text { Avrupa Yükseköğretim Alanı́nda kalite güvencesi } \\
\text { standartlarının ve ilkelerinin kabul edilmesi, yeterlilik- } \\
\text { ler çerçevesi uygulamalarının benimsenmesi }\end{array}$ \\
\hline ¿্ণ & $\begin{array}{c}\text { Londra } \\
\text { Komisyonu }\end{array}$ & $\begin{array}{l}\text { Avrupa Kalite Güvence Birimi'nin kurulması, vize ve çalışma } \\
\text { iznine iliş̧kin zorlukların aşılması, Bologna sürecinin küresel } \\
\text { boyutunun geliştirilmesi }\end{array}$ \\
\hline ஓి & $\begin{array}{c}\text { Leuven } \\
\text { Komisyonu }\end{array}$ & $\begin{array}{l}\text { Bologna araçlarının uygulanmasına devam edilmesi } \\
\text { Avrupa Yükseköğretim Alanı için ilişkilendirici bir } \\
\text { odak konusu olarak kalitenin benimsenmesi, Bologna } \\
\text { politikaları yoluyla küresel politikaların genişletilmesi }\end{array}$ \\
\hline$\stackrel{\sim}{\circ}$ & $\begin{array}{c}\text { Bükreş } \\
\text { Komisyonu }\end{array}$ & $\begin{array}{l}\text { Akademik yeterliliklerin otomatik olarak tanınması, } \\
\text { ulusal yeterlilikler çerçevesini henüz oluşturmamış } \\
\text { ülkeler için yeni yol haritası belirlenmesi, erişim geniş- } \\
\text { letme politikalarının güçlendirilmesi ve tamamlama } \\
\text { oranlarının yükseltilmesi, istihdam edilebilirlik, yaşam } \\
\text { boyu öğrenme, girişimcilik becerilerinin geliştirilmesi, } \\
\text { Bologna araçlarının öğrenme kazanımlarına dayalı ol- } \\
\text { masının sağlanması, EQAR'a kayıtlı ajansların EHEA'da } \\
\text { faaliyetlerinin gerçekleştirilmesinin sağlanması }\end{array}$ \\
\hline
\end{tabular}

Kaynak: Aktan, 2007 s.10; Bakioğlu ve Baltacı, 2010 s.216; YÖK, 2007 s.30. Aktan, 2007 s.145-146, EUA, 2015 
Avrupa Birliği (AB)'nde eğitim akreditasyonunun sağlanabilmesi için oluşturulan Avrupa Yeterlilikler Çerçevesi, öğrenme kazanımları üzerine kurulmuştur. Bologna sürecine dahil ülkeler, bu çerçeveler doğrultusunda yeterlilikler çerçevesini hazırlamış ve hazırlamaya devam etmektedir (Günay, 2012). Bu sayede, Bologna sürecine katılan ülkelerin yükseköğretim sistemleri arasında uyum sağlanabilecektir (Edinsel, 2008). Mesleki eğitim ve öğretimde Avrupa Kalite Güvencesi sisteminde ise; iç ve diş değerlendirme, akreditasyon kuruluşlarının yetkilendirilmesi ve izlenmesi yöntemleri yer almaktadır (Cedefop, 2011, s. 3).

\section{TÜRKIYE'DE YÜKSEKÖĞRETIMDE KALITE GÜVENCE SISTEMI}

Ülkemizde “yükseköğretimde kalite” kavramı 1990’lı yılların sonlarına doğru tartışılmaya başlanmıştır. Yükseköğretimde kalitenin sağlanmasına yönelik çalışmalar $A B D$ ve İngiltere'de Eğitim Fakültelerindeki akreditasyon modellerinin incelenmesi ile devam etmiş ve ilerleyen yıllarda belirli üniversitelerde kalitenin nasıl sağlanacağ ${ }_{1-}$ na ilişkin pilot uygulamalar yapılmıştır (Eri ve Durman, 2011).

Ülkemizin Avrupa Yükseköğretim Alanı'na katılımında Bologna kriterlerinin uygulanmaya başlanması ve bu kriterlerin gereği olarak yükseköğretimin yapısındaki değişimler, müfredatların yapılandırılması, idari birimlerin sürece katılımı, öğrenci merkezli öğrenme, öğrenme kazanımlarının belirlenmesi ile ilgili adımlar kalite sürecinde belirleyici olmuştur (Gümrükçü, 2011).

\subsection{Bologna Sürecinden Önce Türkiye'de Yükseköğretimde Kalite Konusunda Gelişmeler}

Türkiye'de Bologna süreci öncesinde kalite güvencesi ile ilgili çeşitli girişimler olmuş ve bazı çalışmalar yapılmıştır. 1981 yılında 2547 Sayılı Yükseköğretim Kanunu çıkarılmış, 1982 yılında Anayasa'nın 130 ve 131. maddelerinde Yükseköğretim Kurulu (YÖK), yükseköğretim kurumlarından sorumlu tek kurum haline getirilmiş, 1994 yılında Orta Doğu Teknik, Hacettepe, Boğaziçi, İstanbul Teknik ve Doğu Akdeniz üniversitelerindeki bazı mühendislik programları Accreditation Board for Engineering and Tecnology, Inc (ABET) tarafından akredite edilmiş, 1997 yılında Türk üniversitelerinde Kalite Değerlendirme Projesi başlatılmış ve 1998-1999 yılları arasında Türkiye'de Öğretmen Eğitimi Kalitesinin Geliştirilmesi ve Akreditasyonunun Sağlanması ile ilgili çalışmalar başlatılmıştır (Platin, 2003).

1997 yılında YÖK ile İngiltere Konsolosluğu tarafından başlatılan Türk Üniversiteleri Kalite Değerlendirme Projesi kapsamında sekiz üniversitenin on üç farklı bölümlerinde $\mathrm{OECD}$ ve $\mathrm{AB}$ ülkelerindeki yükseköğretim kurumlarının kalite güvence sistemlerine benzer bir sistemin oluşturulabilmesi için pilot çalışma yapılmış ve çalışma ile ilgili rapor hazırlanmış olmasına rağmen projede alınan kararlar uygulanamamıştır (Durman, 2007). 1998 yılının Haziran ayında Öğretmen Yönetimi Milli Komitesi üyeleri ve proje yönetimi, akreditasyon süreçlerini inceleyebilmek için ABD ve İngiltere'ye ziyaretlerde bulunmuş ve bu ülkelerdeki izlenimlerini raporlamışlardır. Rapor, Millî Eğitim Bakanlığı (MEB) ve Eğitim Fakülteleri öğretim üyeleri ile paylaşılmıştır (Kavak, 2007). Yürütülen proje kapsamında; öğretim elemanları, öğrenciler, tesis-

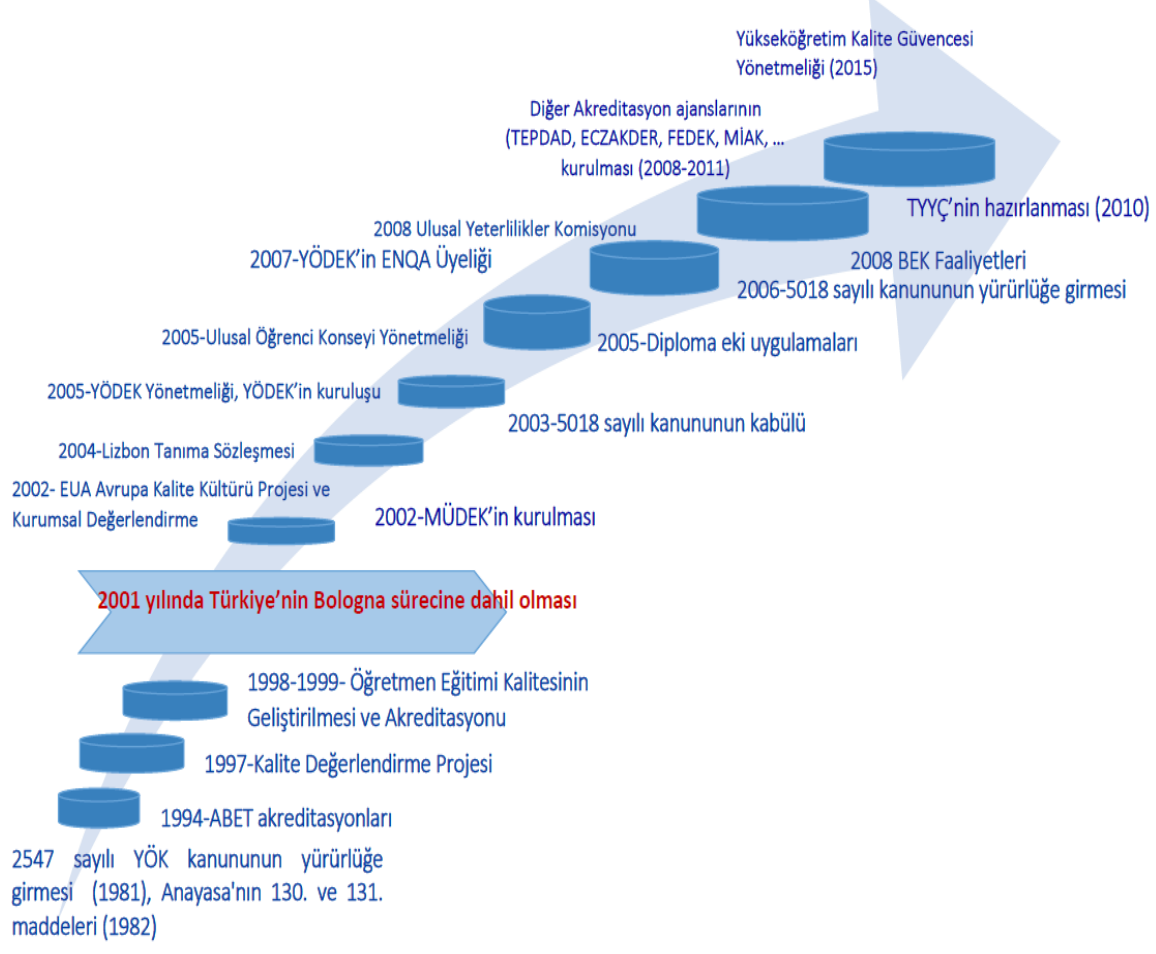

Şekil 1: Türkiye'de Yükseköğretimde Kalite 
ler, kütüphane, yönetim, öğretimin planlanması, uygulanması ve değerlendirilmesi ile kalite güvencesi konularında her bir boyuta ilişkin süreçler ve standartlar belirlenmiştir (Yelken vd., 2007).

\subsection{Bologna Süreci Kapsamında Türkiye'de Yükseköğretimde Kalite}

2001 yılında Türkiye, Bologna sürecine katılmış ve Türkiye'de Mühendislik Dekanlar Konseyi kurulmuştur. Mühendislik Dekanlar Konseyi, ABET'e benzer ulusal kalite güvence sisteminin oluşturulabilmesi yönündeki ilk adımdır (Süngü ve Bayrakçı, 2010). 2002 yılında mühendislik programlarının değerlendirilebilmesi için Mühendislik Dekanlar Konseyi tarafından Mühendislik Değerlendirme Kurulu oluşturulmuştur (Serbest, 2009). Ayrıca, mühendislik programları için ülkemizde ulusal kalite güvence sisteminin oluşumuna ilk örnek olan Mühendislik Eğitim Programları Değerlendirme ve Akreditasyon Birliği (MÜDEK) 2007 yılında YÖK tarafından tanınmıştır.

Üniversitelerde Bologna sürecine uygun kalite güvence sistemlerinin oluşturulabilmesi, kalite kültürünün yükseköğretim kurumlarında yaygınlaştırılabilmesi için 2002 yılında Avrupa Üniversiteler Birliği (EUA) tarafından gerçekleştirilen Kalite Kültürü Projesi’ne Boğaziçi, Yıldız Teknik ve Uludağ üniversiteleri katılmıştır. Projenin 2003-2004 yılı döneminde kırk beş Avrupa üniversitesi arasından Uludağ Üniversitesi ile KU Leuven Üniversitesi, Bologna reformlarının uygulanmasında en iyi iki örnek üniversite olarak seçilmişlerdir (Şenol, t.y.).

2002 yılında Bakanlar Kurulu kararı ile Devlet Planlama Teşkilatı bünyesinde AB Eğitim ve Gençlik Programları Dairesi kurulmuştur. AB Eğitim ve Gençlik Programları Merkezi Başkanlığı (Türkiye Ulusal Ajansı) 2003 yılında tüzel kişiliği haiz, idari ve mali özerkliğe sahip bir kuruluş haline gelmiş ve 2004 yılında AB Eğitim ve Gençlik Programları'nın tam üyesi olmuştur.

Ülkemizde AB'ye uyum süreci, kamu yönetimi alanında bazı düzenlemeleri gerekli kılmış, 2003 yılında 5018 Sayılı Kamu Mali Yönetim ve Kontrol Kanunu yürürlüğe girmiştir ${ }^{4} 5018$ Sayılı Kanun kapsamında kamu kurumlarının stratejik planlama yapması zorunlu hale gelmiş, Kamu İdarelerinde Stratejik Planlamaya İlişkin Usul ve Esaslar Hakkında Yönetmelik hükümleri uyarınca stratejik planlamanın usul ve esasları belirlenmiştir (Gürer, 2006). Böylelikle, belirli kural ve standartlara sahip iç denetim sistemi oluşturulmuştur (Coşkun, 2011). Girdi odaklı mali sistem yerini performansa dayalı ve çıtı odaklı mali sisteme bırakmıştır (Kesik ve Kıral, 2012).

Tüm yükseköğretim kurumlarımızda tanınırlık amacıyla kullanılan diploma eki uygulamalarının ön lisans, lisans, yüksek lisans ve doktora derecesinde ayrı ayrı düzenlenmesi 1 Mart 2005 tarihli YÖK Genel Kurul kararı uyarınca zorunlu hale getirilmiştir ${ }^{5}$.

\footnotetext{
${ }^{4} 5018$ sayılı Kamu Mali Yönetim ve Kontrol Kanunu, 24.12.2013 tarih ve 25326 Sayılı Resmî Gazete.

${ }^{5}$ http://www.yok.gov.tr/web/uluslararasi-iliskiler/sss (22.10.2016).
}

Öğrencilerin yükseköğretim kurumlarında eğitim öğretim ile ilişkili kararlara katılımını sağlayan ve eğitim, sağlık, spor gibi ihtiyaçların karşılanmasını amaçlayan Yükseköğretim Kurumları Öğrenci Konseyleri ve Yükseköğretim Kurumları Ulusal Öğrenci Konseyi Yönetmeliği 20.09.2005 tarih ve 25942 sayılı Resmî Gazete'de yayımlanarak yürürlüğe girmiştir. Bu yönetmelikle birlikte, öğrencilerin sürece aktif katılımı ile ilgili olarak önemli bir adım atılmıştır (YÖK), 2007, s. 32-33). Aynı tarih ve sayılı Resmî Gazete'de, Yükseköğretim Kurumlarında Akademik Değerlendirme ve Kalite Geliştirme Yönetmeliği yayımlanarak yürürlüğe girmiştir. Bu yönetmelikle, YÖK tarafından yükseköğretim kurumlarının eğitim, öğretim ve araştırma faaliyetleri ile idari hizmetlerinin değerlendirilmesi, kalitenin geliştirilmesi, bağımsız dış değerlendirme süreci ile kalite düzeylerinin onaylanması ve tanınması konusundaki çalışmalara ilişkin esaslar düzenlenmiştir. YÖK Başkanlığı tarafından Yükseköğretim Kurumlarında Akademik Değerlendirme ve Kalite Geliştirme Yönetmeliği’nde Değişiklik Yapılmasına Dair Yönetmelik, 28.12.2006 tarih ve 26390 sayılı Resmî Gazete'de yayımlanmış; bu yönetmelikle birlikte, Yükseköğretim Kurumlarında Akademik Değerlendirme ve Kalite Geliştirme Komisyonu (YÖDEK) kurulmuştur'. YÖDEK'in, Avrupa Yükseköğretim Kalite Güvence Birliği (European Association for Quality Assurance in Higher Education System - ENQA)'ne üyeliği 15.06.2007 tarihinde kabul edilmiştir (Ayvaz vd., 2016). Yükseköğretim kurumlarının akademik değerlendirme ve kalite geliştirme çabalarını düzenli olarak yürütebilmeleri için 2007 yılında YÖDEK tarafından Yükseköğretim Kurumlarında Akademik Değerlendirme ve Kalite Geliştirme Rehberi hazırlanmıştır (YÖDEK, 2007).

Bergen'de yapılan Bologna Bakanlar Zirvesi'nden sonra Türkiye'de de yükseköğretim yeterlilikleri ile ilgili çalışmalar başlatılmış ve 2008 yılında YÖK bünyesinde Ulusal Yeterlilikler Komisyonu ve Çalışma Grubu çalışmalarına başlamıștır ${ }^{7}$ MEB, YÖK ve Mesleki Yeterlilikler Kurumu (MYK)'nun üst düzey temsilcilerinden oluşan Ulusal Yeterlilikler Çerçevesi Hazırlama Komisyonu 2010 yılında kurularak çalışmalarına başlamıştır.

2014 yılında YÖK bünyesinde, istatistiki bilgilerle yükseköğretim kurumlarının mevcut durumlarını ortaya koymayı amaçlayan ve yükseköğretimle ilgili karar verme süreçlerinde kaliteyi artırmayı hedefleyen Yükseköğretim Bilgi Yönetim Sistemi (YBYS) kurulmuştur. Bu sayede, daha önce Öğrenci Seçme ve Yerleştirme Merkezi (ÖSYM) tarafından yayımlanan yükseköğretim istatistiklerinin, YÖK tarafından yayımlanması sağlanmıştır (YÖK, 2014, s. 42).

5544 Sayılı MYK Kanunu'nun 23/A maddesinde bulunan ulusal yeterlilikler çerçevesi ifadesi Türkiye Yeterlilikler Çerçevesi olarak yeniden düzenlenmiş, Türkiye Yeterlilikler Çerçevesinin Uygulanmasına İlişkin Usul ve Esas${ }^{6}$ www.yodek.org.tr (24.10.2016).

${ }^{7}$ http://www.yok.gov.tr/web/uluslararasi-iliskiler/tyyc-genel (11.10.2016) 
lar Hakkında Yönetmelik 19.11.2015 tarih ve 29357 sayılı Resmî Gazete'de yayımlanarak yürürlüğe girmiştir8.

\section{YÜKSEKÖĞRETIM KALITE KURULU}

\subsection{Yönetmelik ve Sonrası Süreç}

Yükseköğretim kurumlarında kalite güvencesi, eğitim-öğretim, araștırma ve geliștirme, yönetim sistemleri, bağımsız dış değerlendirme kuruluşlarının yetkilendirilmesi, bu süreçlere ilişkin esasların düzenlendiği Yükseköğretim Kalite Güvencesi Yönetmeliği, başta yükseköğretim kurumları olmak üzere diğer paydaşların da görüşleri alınarak hazırlanmış, 23.07.2015 tarih ve 29423 sayılı Resmî Gazete' de yayımlanarak yürürlüğe girmiștir. $\mathrm{Bu}$ yönetmelik kapsamında oluşturulan Yükseköğretim Kalite Kurulu yirmi bir kişiden oluşmaktadır. Bu kurulun çalışma usul ve esasları 17.02.2016 tarihli Yürütme Kurulu toplantısında uygun bulunmuş, Yükseköğretim Kalite Kurulu tarafından Kurumsal Dıș Değerlendirme Komisyonu, Kalite Güvence Ajansları Tescil Komisyonu, Kalite Kültürünü Yaygınlaştırma Komisyonu oluşturularak üyeleri belirlenmiștir9.

Yükseköğretim Kalite Güvencesi Yönetmeliği, yükseköğretim kurumlarının eğitim-öğretim, araştırma faaliyetleri ile idari hizmetlerinin iç ve dış kalite güvencesi, akreditasyon süreçleri bağımsız dış değerlendirme kurumlarının yetkilendirilmesi süreçlerini ve bu kapsamda tanımlanan görev, yetki ve sorumluluklara ilişkin esasları düzenlemektedir. İlgili yönetmelikle kalite güvencesi iç değerlendirme, dış değerlendirme, dış değerlendiricilerin onayı ve izlenmesi olmak üzere üç bölümde ele alınmaktadır ${ }^{10}$.

Yükseköğretim Kurulu Kalite Güvencesi; eğitim-öğretim, araştırma faaliyetleri, yönetim sistemi konularının işleyişi hakkında kurumdaki mevcut durumu ve bu konulara ilişkin faaliyetlerin nasıl yürütüldüğü ile ilgili kurumsal iç değerlendirme raporu (KIDR)'nu hazırlarken, kurumun güçlü taraflarını ve iyileștirmeye açık yönlerini ortaya koyabilen bir rapor hazırlamalıdır (YKK, 2016, s. 3-5).

Yükseköğretim kurumunun kalite güvence sistemini nasıl oluşturduğu, izlemelerin ne șekilde yapıldığı, iyileştirmeye dair nelerin planlandığı ve bu kapsamda ortaya konacak kanıtlar, dıș değerlendirme sürecine esas teşkil etmektedir. Dıș değerlendirme sürecinde hareket noktası iç değerlendirme raporlarıdır (YKK, 2016, s. 17). Yükseköğretim kurumları dış değerlendirme sürecine gönüllü olarak katılmaktadır. Kalite Kurulu tarafından kurumsal dıș değerlendirme sürecinde yapılacak değerlendirmelerde yol gösterici olması için "Kurumsal Dış Değerlendirme Kılavuzu" hazırlanmıștır ${ }^{11}$.

\footnotetext{
${ }^{8}$ Türkiye Yeterlilikler Çerçevesinin Uygulanmasına Ilişkin Usul ve Esaslar Hakkında Yönetmelik, 19.11.2015 tarih ve 29537 Sayılı Resmî Gazete ${ }^{9}$ http://www.yok.gov.tr/documents/23233405/23540205/USUL+VE+ESASLAR_tarih.pdf/884573de-9f3a-4989-9847-e6ce31776e80 (12.12.2016). ${ }^{10}$ Yükseköğretim Kalite Güvencesi Yönetmeliği, 23.07.2015 tarih ve 29423 Sayılı Resmî Gazete.

${ }^{11}$ http://www.yok.gov.tr/documents/23233405/23540205/yok+kitapcik+baski. pdf/ce3d7253-affc-487f-a2ee-54e13997fc6b (04.12.2016).
}

Tablo 3. Kurumsal iç̧ Değerlendirme Raporu Bileşenleri

\begin{tabular}{|c|c|}
\hline Konu & İçerik \\
\hline $\begin{array}{l}\text { Kurum } \\
\text { Hakkında } \\
\text { Bilgiler }\end{array}$ & $\begin{array}{l}\text { - Tarihsel gelişimi } \\
\text { - Vizyonu, misyonu, değerleri, hedefleri } \\
\text { - Eğitim-öğretim hizmeti sunan birimleri } \\
\text { - Araştırma faaliyeti sunan birimleri } \\
\text { - Iyileştirme çalışmaları }\end{array}$ \\
\hline $\begin{array}{c}\text { Kalite } \\
\text { Güvencesi }\end{array}$ & $\begin{array}{l}\text { - Kalite Güvence Süreçleri, kurumsal dış değerlendirme, prog- } \\
\text { ram akreditasyonu, sertifikalar, yürütülen çalışmalar, devam } \\
\text { etmekte olan süreçler } \\
\text { - Süreçlerin iyileştirilmesi, Kalite Kurulu Komisyonu'nun nasıl } \\
\text { oluşturulduğu, belirlenen performans göstergeleri ve izleme } \\
\text { - Iç ve dış paydaşların Kalite Güvence Sistemi'ne katkısı }\end{array}$ \\
\hline $\begin{array}{l}\text { Eğitim- } \\
\text { Ögrretim }\end{array}$ & $\begin{array}{l}\text { - Programların tasarımı ve onay süreci ve sürece dış paydaş- } \\
\text { ların katııımı, bilgi, beceri ve yetkinliklerin belirlenmesi, TYYÇ } \\
\text { ile uyumu } \\
\text { - Öğrenme kazanımları, AKTS'lerin belirlenmesi, programla- } \\
\text { rın izlenmesi } \\
\text { - Öğrenci merkezli öğrenme, öğrencilerin sürece katılımı } \\
\text { - Kaynaklara erişilebilirlik } \\
\text { - Eğitim-öğretim kadrosunun nitelik ve niceliği }\end{array}$ \\
\hline $\begin{array}{l}\text { Araştırma- } \\
\text { Geliştirme }\end{array}$ & $\begin{array}{l}\text { - Araştırma stratejisi ve hedefleri } \\
\text { - Araştırma kaynakları } \\
\text { - Araştırma kadrosu } \\
\text { - Araşırma performansının izlenmesi ve iyileştirilmesi }\end{array}$ \\
\hline $\begin{array}{l}\text { Yönetim } \\
\text { Sistemi }\end{array}$ & $\begin{array}{l}\text { - Kurumun yönetişim süreçleri ve faaliyetleri } \\
\text { - Yönetimin stratejisi, hedeflere nasıl ulaşılıyor? } \\
\text { - Kaynakların yönetimi } \\
\text { - Bilgi Yönetim Sistemi'nin işleyişi } \\
\text { - Yönetimin hesap verebilirliği, kamuoyuna açıklık }\end{array}$ \\
\hline
\end{tabular}
Kaynak: YKK (2016).

Türkiye'de Yükseköğretim Kalite Güvencesi Yönetmeliği ile yükseköğretim kurumlarının yurtdışı değerlendirmelerine tabi olabilmesinin önünde herhangi bir engel yoktur. YÖK tarafından tanınan ve Yükseköğretim Kalite Kurulu tarafından yetkilendirilen "Kalite Değerlendirme Tescil Belgesine" sahip dış değerlendirme kuruluşları da değerlendirme faaliyeti gösterebilmektedirler (Borat, 2011). Bu kapsamda; Eczacllık Eğitimi Programlarını Değerlendirme ve Akreditasyon Derneği (ECZAKDER), Eğitim Fakülteleri Programlarını Değerlendirme ve Akreditasyon Derneği (EPDAD), Fen, Edebiyat, Dil ve Tarih Coğrafya Fakülteleri Öğretim Programları Değerlendirme ve Akreditasyon Derneği (FEDEK), Hemşirelik Eğitim Programları Değerlendirme ve Akreditasyon Derneği (HEPDAK), Mimarlık Akreditasyon Kurulu (MİAK), Mühendislik Eğitim Programları Değerlendirme ve Akreditasyon Derneği (MÜDEK), Tıp Eğitimi Programlarını Değerlendirme ve Akreditasyon Derneği (TEPDAD), Veteriner Hekimliği Eğitim Kurumları ve Programları Değerlendirme ve Akreditasyon Derneği (VEDEK) faaliyet göstermektedir.

\subsection{Yasa: Yeni Bir Başlangıç?}

1 Temmuz 2017 tarihinde 30111 sayılı Resmî Gazete'de yayımlanarak yürürlüğe giren 7033 Numaralı "Sanayinin Geliștirilmesi ve Üretimin Desteklenmesi Amacıyla Bazı Kanun ve Kanun Hükmünde Kararnamelerde Değişiklik Yapılmasına Dair Kanun”un Ek 35. Maddesi'nde Yükseköğretim Kalite Güvence Sistemi ve Yükseköğretim Kalite Kurulu'na ilişkin düzenlemeler yer almaktadır.

Temel olarak bakıldığında yönetmelik ve yasa aynı ruhu yansıtmakla birlikte aralarında bazı nüanslar bulunmak- 
tadır. Öncelikle yasalaşma kalite süreçlerinin dayanak noktasını kesin bir biçimde güçlendirmektedir. İkincisi Kalite Kurulu üye sayısı ve muhtevası değişmiş olmakla birlikte otonom bir kurum haline gelmesi hem bağımsızlığını hem de teknik kapasitesini güçlendirmesi anlamına gelmektedir. Kalite standartlarının oluşturulması ve iç-dış değerlendirmelerin yapılmasının açı hükümlere bağlanması üniversitelerin nitelik yönelimini güçlendirmesi beklenmektedir. Elbette yasa YÖK'ün yeni YÖK kapsamında başlattığı bir dizi dönüşümün parçasıdır ve bu bağlamda daha geniş ve zengin bir perspektifin uzantısıdır.

Ne var ki ülkemizin pratikleri yasal düzenlemelerin kabullenilmesi ve uygulamaya yansıtılmasının bir süreç içerdiği göstermektedir. Bologna süreci bunun en açık örneklerinden birisidir. Bologna süreci ilk etapta biçimsel bir değişime yol açmış, sahiplenilmesi ve uygulanması zaman içerisinde gerçekleşmiștir. Çok farklı üniversitelerin çok farklı coğrafyalarda faaliyet göstermesi genel geçerli kalite ilkelerinin diğer bir ifade ile kalitenin ana iskeletinin oluşmasının zaman alacağının göstergesi olarak kabul edilebilir. Yasa ile beklentilerin yükselmesi ve bu beklentilerin kısa vadede karşılanamaması hayal kırıklığı oluşturma riskini doğal olarak bünyesinde barındırmaktadır. Nitelik hususunun işin doğasında olan kısmı bürokratik ve teknik bakışla çözümlenebilir bir süreç değildir. Kalitenin aşırı gösterge odaklı algılanması işin doğası ya da ruhundaki özelliklerin kaybolmasına ya da en azından görünmemesine yol açabilir. Kaldı ki bu konuda ülke olarak deneyimin sınırlı olması ortak dilin kurgulanmasını zorlaştırabilir. Hem hız hem de nitelin birlikte arandığı rekabet ortamının formal kalite ve informal kalite arasında sıkışmalara yol açabileceği göz ardı edilmemelidir.

\section{5. ÇALIŞMAYA KONU OLAN ÜNIVERSITELERIN KURUMSAL IÇ DEĞERLENDIRME RAPORLARINDA EĞITIM BOYUTUNUN DEĞERLENDIRILMESI}

Kurum İç Değerlendirme Raporu (KIDR); kurumun yıllık iç değerlendirme süreçlerini izlemek ve beş yll içinde en az bir defa gerçekleștirilecek dıș değerlendirme sürecinde esas alınmak üzere, kurum tarafından her yıl hazırlanmaktadır. KIDR, Avrupa Standartlar Rehberi'nden esinlenerek yapılan bir uygulamadır. Kurum tarafından hazırlanacak iç değerlendirme raporunun aşağıdaki soruların cevabını içerecek şekilde hazırlanması beklenmektedir:

- Kurum ne yapmaya çalışıyor? (Kurumun misyonu ve hedefleri)

- Kurum misyon ve hedeflerine nasıl ulaşmaya çalış1yor? (Kurumun yönetişim/organizasyonel süreçleri ve faaliyetleri)

Kurum misyon ve hedeflerine ulaştığına nasıl emin oluyor? (Kalite güvencesi süreçleri, İç değerlendirme süreçleri)

Kurum geleceğe yönelik süreçlerini nasıl iyileştirmeyi planlıyor? (Yükseköğretimin hızlı değișen gündemi kapsamında kurumun rekabet avantajını koruyabilmesi için sürekli iyileşme faaliyetleri)

KIDR, kalite güvencesi, eğitim-öğretim, araştırma-geliștirme ve yönetim sistemi olmak üzere 4 ana başlıktan oluşmakta ve eğitim-öğretim bu çalışmanın temelini oluşturmaktadır.

Tablo 4'te çalışmaya konu olan üniversitelerin KIDR incelemesi sonuçlarına yer verilmiş ve sonrasında açıklama yapılmıştır.

Tablo 4. Çalışmaya Konu Olan Üniversitelerin Durumu

\begin{tabular}{|c|c|c|c|}
\hline Sıra & $\begin{array}{l}\text { KiDR'lerde Ele Alınan Konu } \\
\text { Başlıkları }\end{array}$ & Üniversite & Frekans \\
\hline 1 & İç ve Dış Paydaşların Sürece Katılımı & PAÜ, SAÜ, SDÜ & 3 \\
\hline 2 & $\begin{array}{l}\text { Eğitim-Öğretim Kadrosunun Per- } \\
\text { formansı }\end{array}$ & ADÜ, SDÜ, PAÜ, SAÜ & 4 \\
\hline 3 & $\begin{array}{l}\text { Özel Yaklaşım Gerektiren Öğrencile- } \\
\text { re Yönelik Hizmetler }\end{array}$ & $\begin{array}{l}\text { ADÜ, KOÜ, SAÜ, } \\
\text { SDÜ }\end{array}$ & 4 \\
\hline 4 & Öğrenci Oryantasyon Programları & $\begin{array}{l}\text { ADÜ,KOÜ, PAÜ, } \\
\text { SAÜ, SDÜ }\end{array}$ & 5 \\
\hline 5 & Öğrenme Kaynaklarının Zenginliği & $\begin{array}{l}\text { ADÜ,KOÜ, PAÜ, } \\
\text { SAÜ, SDÜ }\end{array}$ & 5 \\
\hline 6 & $\begin{array}{l}\text { Öğrencilere Yönelik Kariyer Geliştir- } \\
\text { me Hizmetleri }\end{array}$ & $\begin{array}{l}\text { ADÜ,KOÜ, PAÜ, } \\
\text { SAÜ, SDÜ }\end{array}$ & 5 \\
\hline 7 & Öğrenci Memnuniyeti & ADÜ, PAÜ, SAÜ & 3 \\
\hline 8 & Mezun İzleme Sistemi & $\begin{array}{l}\text { ADÜ,KOÜ, PAÜ, } \\
\text { SAÜ, SDÜ }\end{array}$ & 5 \\
\hline
\end{tabular}

Üniversitenin mezunlarla ilişkisi, günümüzde kalitenin en önemli boyutlarından birini oluşturmaktadır. İncelemeye konu olan beş üniversite KIDR'inde mezun izleme sistemi bulunduğu yer almaktadır. Doktora mezunlarının yurtiçi ve yurtdışı üniversitelerde öğretim görevlisi olarak işe başlama oranlarının takibi sadece SDÜ'de yapılabilmektedir. PAÜ ve SAÜ mezun anketi uygulaması yapmakta, KOÜ ve SDÜ mezunlarla mail, telefon ve sosyal platformlar aracıllğıyla iletişimde kalmakta ve ADÜ ise en iyi onlar projesini uygulamaktadır.

Kariyer geliştirme hizmetleri, mezun sisteminin devamı olarak görülebilecek bir husustur. Öğrencilerin, eğitim-öğretimi sahiplenmesi önemlidir. Çalışmaya konu olan üniversitelerde kariyer günleri ile teknik geziler düzenlenmekte ve staj imkanları sunulmakta, ADÜ hariç diğer üniversiteler TTO hizmetleri vermekte, SDÜ hariç diğer üniversiteler sertifika programları ve kurslar açmakta, SAÜ ve SDÜ öğrencilere kısmi zamanlı çalışma imkânı vermektedir. SDÜ, TÜBİTAK Üniversite Öğrencileri Destekleme Programı kapsamında öğrencilere roller verilmesi yoluyla mesleki gelişimi desteklemesi, Kariyer Planlama ve Mezunlarla İletişim Uygulama ve Araştırma Merkezi'nin kurulması açısından diğer üniversitelerden ayrilmaktadır.

Öğrencilerin memnuniyeti ve bu memnuniyetin izlenip ölçülmesi bir başka önemli noktayı oluşturmaktadır. $\mathrm{Bu}$ açıdan bakıldığında, öğrenci memnuniyetinin çeşitli araçlarla ölçülmesi ve veri akışının sağlanması mümkündür. Çalışmaya konu olan üniversiteler, öğrenci memnuniyeti- 
ni ölçmek için öncelikle öğrenci memnuniyet anketlerini kullanmaktadır. ADÜ, KOÜ ve PAÜ'de program yeterlilikleri değerlendirilmektedir. PAÜ'de öğrenme kazanımlarının ve dersin değerlendirilmesi söz konusudur. PAÜ, SAÜ ve SDÜ'de öğrenci temsilcileri senato toplantılarına katılmaktadır. PAÜ Kalite Yönetimi ve Veri Değerlendirme Araştırma ve Uygulama Merkezi ile çalışmaya konu olan diğer üniversitelerden farklılaşmaktadır. SAÜ ise eğitim-öğretim idari hizmetleri değerlendirme anketleri, uygulamalı eğitim süresince yapılan anketler, şikâyet yönetim sistemi, anket geliştirme ve değerlendirme komisyonu ve öğrenci dekanlığı birimi ile farklılık göstermektedir.

Öğrenme kaynaklarının zengin olması, öğrenci memnuniyetini sağlayan ve üniversiteleri rekabette ön plana çıkaran bir faktör olarak göze çarpmaktadır. Çalışmaya konu olan üniversitelerde PAÜ hariç uzaktan eğitim sistemi bulunmaktadır. SAÜ ve SDÜ 7/24 kütüphane hizmeti vermektedir. ADÜ hariç Teknoloji Transfer Ofisi faaliyetleri yürütülmektedir. PAÜ, Moodle Açı Kaynak Erişimi Yönetimi Platformu ile "blended" öğrenmeyi teşvik etmekte ve diğer üniversitelerden ayrılmaktadır.

Öğrencilerin yaşadığı şehre adapte olabilmesi, üniversitenin beklentilerini karşılayabilmesi ile yakından ilgilidir. Dolayısıyla öğrenci oryantasyon programları, öğrenci memnuniyetinin basamaklarından birini oluşturmaktadır. Bu kapsamda, ADÜ uluslararası oryantasyon günü düzenlemekte ve diğer üniversitelerde oryantasyon programı bulunmaktadır. KOÜ kent tanıtımı ve bilgilendirme toplantıları yapmakta, SAÜ tanıtım web sayfası ve videoları oluşturmakta ve tanıtım günleri düzenlemekte, SDÜ ise öğrenci kulüplerinin desteği ile yeni başlayan öğrencilerin gelişimine destek olabilecek faaliyetlerin tanıtımını yapmaktadır.

5378 Sayılı Engelliler Hakkında Kanun gereğince üniversitelerde engelli öğrencilere eğitim-öğretim süreçlerinde destek verebilmek amaciyla merkez, birim veya koordinatörlükler kurulmuştur. ADÜ'de Eğitim Fakültesi bünyesinde seçmeli İşaret Dili dersi bulunmakta, GEKOP'a üyelik, fiziksel engelliler için altyapının düzenlenmesi vb. faaliyetler planlanmaktadır. KOÜ’de kayıt döneminde asistanlık hizmeti ile Telefon Kütüphanesi Projesi ile telefonda sesli kitap hizmeti verilmekte, Milli Kütüphane konuşan kitaplığa üyelik sağlanmakta ve Braille Alfabesi yöntemiyle İngilizce eğitim verilmektedir. SDÜ'de Engelliler Araştırma ve Uygulama Merkezi bulunmakta ve Engelsiz Yerleşke Projesi gerçekleştirilmektedir. SAÜ'de binaların iyileştirilmesi ihtiyacı hariç engelli öğrencilerle ilgili yapılan düzenlemelere yer verilmemiştir.

Programın eğitim amaçlarının ve müfredatın belirlenmesinde iç ve dış paydaşların sürece katılımı önem arz etmektedir. Bu kapsamda; KOÜ ihtiyaç analizi çalıştayı düzenlemekte, PAÜ "Paydaş İletişim Ofisi" kurulmasını planlamakta, SAÜ SABİS aracılığıyla dış paydaşlarla iletişim kurmakta ve eğitim-öğretim programlarının yeniden yapılandırılması projesini uygulamakta, SDÜ "Kariyer Planlama ve Mezunlarla İletişim Uygulama ve Araștırma Merkezi"ni hayata geçirmektedir.

Üniversitelerin eğitim-öğretim kadrosunun performanS1, öğrenci memnuniyetini sağlayan diğer bir husustur. Bu kapsamda, çalışmaya konu olan üniversitelerde eğitim-öğretim kadrosunun performansının izlenmesine ve ödüllendirilmesine yönelik mekanizmalar incelenmiştir. SAÜ'de "Bilim, Sanat, Hizmet ve Teșvik Ödülleri Yönergesi" bulunmakta, SDÜ'de ise "Ödül Yönergesi" bulunmaktadır. SDÜ hariç diğer üniversiteler, öğretim elemanı değerlendirme anketi uygulamaktadırlar. PAÜ, Tip Fakültesi'nde öğrenci ve öğretim elemanlarından alınan geri bildirimler sonucu döner sermaye kaynaklarından performansı ödüllendirmekte ve diğer üniversitelerden ayrilmaktadır.

\section{SONUÇ}

Sanayi toplumundan, bilgi toplumuna geçiş ve küreselleşmeyle birlikte bilgi üretiminin kaynağını oluşturan yükseköğretim kurumlarının önemi artmış, nitelikli insan gücünün yetiştirilmesi ve bu insan gücünün ürettiği bilgi yoluyla ekonomik kalkınmanın sağlanabilmesi önem kazanmıştır (Sakınç ve Bursalıoğlu, 2012 s.98).

Sakarya ve Süleyman Demirel üniversitelerinde yeni bir program açılırken dış paydaşların görüşleri alınmaktadır. Sakarya Üniversitesi'nde kurulmuş olan SABİS sistemi ile dış paydaşlarla iletişim daha kolay bir şekilde gerçekleşmektedir. SDÜ'de diş paydaşlarla iletişimin daha kolay sağlanabilmesi için Kariyer Planlama ve Mezunlarla İletişim Uygulama ve Araştırma Merkezi'nin kurulma kararı alınmıştır. Öğretim elemanlarının performansı yapılan anketlerle, bilgi sistemleri ve yıllık raporlar aracllğ̆ıla izlenebilmektedir. Genel olarak üniversitelerde ödüllendirmeye ilişkin yönergeler mevcuttur. 5378 sayılı Engelliler Hakkında Kanun gereğince, "Yükseköğretim Kurumları Engelliler Danışma ve Koordinasyon Yönetmeliği” 14.08.2010 tarih ve 27672 sayllı Resmî Gazete'de yayımlanmış ve üniversiteler engelli öğrenciler için yükseköğretime erişim kolaylığını sağlayabilmek amacıyla fiziki alt yapı, kütüphane hizmetleri, eğitim-öğretim süreçleriyle ilgili düzenlemelere başlamışlardır. Bu çerçevede, tüm üniversitelerde engelli öğrencilerle ilgili çalışmalar başlatılmış ve bu öğrenciler için verilen hizmetler hızla geliştirilmektedir. Bütün üniversitelerde oryantasyon programları düzenlenmekte olup yalnızca bu programlar bazı üniversitelerde çeşitlilik göstermektedir.

Üniversiteler eğitim-öğretimin etkinliğini arttıracak öğrenme ortamlarını atölyeler, uygulama alanları, laboratuvarlar, araştırma ve uygulama merkezleri, uzaktan eğitim merkezleri, kütüphane hizmetleri ile sağlamaktadır. Üniversiteler ilgili öğrenme ortamlarını sürekli iyileștirmektedirler. Zaman içerisinde 7/24 saat kütüphane hizmeti veren üniversitelerin sayısında artış olması umulmaktadir. 
Öğrencilerin mesleki gelişimlerine ve kariyer planlamalarına yönelik olarak tüm üniversitelerde öğrencilerin kariyer gelişimlerini destekleyecek hizmetler verilmektedir.

SAÜ'de anketler için bir komisyon oluşturulmuş olup PAÜ'de ise Kalite Yönetimi ve Veri Değerlendirme Araştırma ve Uygulama Merkezi aracılığıyla anket çalışmaları yürütülmektedir. 1992 yılında kurulmuş üniversitelerin 3'ünde, öğrenci temsilcileri senato toplantılarına da katılabilmektedirler.

Mezun izleme ağının tesisi mezunlar ve üniversite arasında karşılıklı etkileşimin sağlanabilmesi için önemlidir. Üniversite mezunlarının mesleklerindeki mevcut durumlarını, değişiklikleri, mezunlarının meslekteki ilerlemelerini takip edilebilecek, mezunlar ise üniversitelerde yapılan etkinlikler, güncel gelişmeler, çalışmalar ve seminerlerden haberdar olabilecektir. Ayrıca bir programın eğitim amaçlarına ulaşma düzeyinin belirlenebilmesi için mezunların izlenmesi önem taşımaktadır. Mezunların istihdam durumları bir programın eğitim amaçlarına ulaşıp ulaşamadığının en önemli kanıtıdır. Bu kapsamda üniversitelerin KİDR'leri incelendiğinde 1992 yılında kurulmuş üniversitelerin mezun bilgi sistemlerinin olduğu, iyileştirme çalışmalarının devam ettiği görülmektedir. Doktora mezunlarının yurt içi ve yurt dışı üniversitelerde öğretim görevlisi olarak işe başlama oranlarının takibi 1992 yılında kurulmuş üniversiteler arasında tam anlamıyla KOÜ'de yapılabilmektedir.

\section{KAYNAKÇA}

Aktan, C. C. ve Gencel, U., (2007). Yükseköğretimde Akreditasyon. İmir: Yaşar Üniversitesi Yayını, s. 1-14.

Aktan, C. C., (2007a). Yükseköğretimde Değişim: Global Trendler ve Yeni Paradigmalar. Yaşar Üniversitesi Yayını, s. 1-43.

Aktan, C.C. ve Tunç, M., (1999). Bilgi Toplumu ve Türkiye. Yeni Türkiye Dergisi, s. 118-134.

Aydınalp, D., (2011). Almanya, Danimarka, Birleşik Krallık, Avustralya, Amerika Birleşik Devletleri ve Türkiye'de Yükseköğretim Programlarında Kalite Güvencesi ve Akreditasyon Süreci. (Yüksek Lisans Tezi). Ankara Üniversitesi Eğitim Bilimleri Enstitüsü. Ankara, Türkiye.

Ayvaz, B., Kuşakçı, A. ve Borat, O., (2016). Kalite Güvencesi ve Akreditasyon Süreçleri. Yeni Türkiye Dergisi, 88, s. 1-8.

Bakioğlu, A. Ve Baltacı, R., (2010). Akreditasyon Eğitimde Kalite. (1. Baskı). Ankara: Nobel.

Borat, O., (2011). Türkiye Yeterlilikler Çerçevesi Hazırlama Çalışmaları, 15 Haziran 2011. Isstanbul: MYK.

CEDEFOP-European Centre For The Development of Vocational Training (2011). Assuring quality in vocational education and training: The role of accrediting VET providers, Cedefop Reference series; 90. Luxembourg: Publications Office of the European Union.

Coşkun, l., (2011, 25-27 Mart). 5018 Sayılı Yasanın Genel Değerlendirmesi ve AB Sürecinde Mali Kontrol Faslı, Kamu Mali Yönetimi ve Denetimi Sempozyumu.

Çelik, Z., (2012). Bologna Süreci'nin Avrupa Yükseköğretim Sistemi Üzerine Etkileri, Yükseköğretim ve Bilim Dergisi, 3(2), s. 100 105.
Dickey, F. G. ve Miller, J. W., (1972). A Current Perspective On Accreditation. The American Association For Higher Education, Washington DC: The American Association for Higher Education.

Durman, M., (2007). Açıış Konuşması, Eğitim Bilimleri Bakış Açısıyla Eğitim Fakülteleri ve Akreditasyon Çalıştayı 1-3 Mart 2007. Ankara: Ankara Üniversitesi Eğitim Bilimleri Fakültesi Yayınları.

Edinsel, K., (2008). Bologna Sürecinnin Türkiyéde Uygulanması "Bologna Uzmanları Ulusal Takımı Projesi, 2007-2008 Sonuç Raporu.

Eriş, A. ve Durman, M., (2011, 17-19 Haziran). Quality Assurance Activities in Turkish Universities, 22nd International Conference on Higher Education.

EUA-European University Association (2015). Trends 2015: Learning and Teaching in European Universities, by Andrée Sursock. Belgium: EUA

EUA-European University Association (2010). Trends 2010: A Decade of Change in European Higher Education, by Andrée Sursock \& Hanne Smidt, Belgium: EUA

EUA- European University Association (2005). Ankara Üniversitesi EUA Değerlendirme Raporu, Ankara.

Fang, H. Q., (2010). A Comparison of Learning and Teaching Quality Assurance in Chinese and British Undergraduate Education, The Journal of Doctoral Research in Education, Educate, 10 (1), p. 19-35.

Gümrükçü, H., (2011). Bologna Süreci ve Türkiye, Avrupa Yükseköğretim Alanínın Gerçekleştirilmesi. Antalya: Akdeniz Üniversitesi İiBF Yayınları, Yayın No: 6.

Günay D., (2012). Yükseköğretimde Öğrenme Kazanımlarına Dayanan Kalite Güvence Sistemi, İçinde B.S. Gür ve M. Özer (Ed.), Türkiye'de Yükseköğretimin Yeniden Yapılandırılması ve Kalite Güvence Sistemi Çalıştayı. 20 Şubat 2012. Ankara: Siyaset, Ekonomi ve Toplum Araştırmaları Vakfı (SETA).

Gürer, H., (2006). Stratejik Planlamanın Temelleri ve Türk Kamu Yönetiminde Uygulanmasına Yönelik Öneriler. Sayıştay Dergisi, 63, s. 91-105.

Kavak, Y., (2007, 1-3 Mart). Öğretmen Eğitiminde Akreditasyon Denemesi, İçinde T. Kargın ve F.H. Bıkmaz (Yay. Haz), Eğitim Bilimleri Bakış Açısıyla Eğitim Fakülteleri ve Akreditasyon Çaış̧tayı. Ankara: Ankara Üniversitesi Eğitim Bilimleri Fakültesi Yayınları.

Kesik, A. ve Kıral, G., (2012). Yeni Kamu Yönetiminde Hesap Verebilirlik, "Yeni" Maliye Değişim Çağında Kamu Maliyesi: Yeni Trendler, Yeni Paradigmalar, Yeni Öğretiler, Yeni Perspektifler, (Ed. Coşkun Can Aktan, Ahmet Kesik ve Dilek Dileyici), Ankara: T.C. Maliye Bakanlığı, Strateji Geliştirme Başkanlığı, Yayın No: 2012/420.

Kısakürek, M.A., (2007,1-3 Mart). Çeşitli Ülkelerde Akreditasyon, Iç̧inde T. Kargın ve F.H. Bıkmaz (Yay. Haz), Eğitim Bilimleri Bakış Açısıyla Eğitim Fakülteleri ve Akreditasyon Çalıştayı. Ankara: Ankara Üniversitesi Eğitim Bilimleri Fakültesi Yayınları.

Koenig, A. M., Lofstad, R. \& Staab, E., (2004, 18 September). Higher Education Accreditation in the United States, What International Education Proffessionals Need To Know, EAIE Conference.

Özer, M., Gür, B. S. ve Küçükcan, T., (2010). Yükseköğretimde Kalite Güvencesi. Ankara: Siyaset, Ekonomi ve Toplum Araştırmaları Vakfi (SETA). 
Platin, B. E., (2003, 14 Ekim). Ülkemizdeki Mühendislik Eğitiminde Akreditasyon, 12. Ulusal Kalite Kongresi.

Rehber, E., (2007). Dünyada Değişen Yüksek Öğretim ve Kalite Anlayışı, Değişim Çağında Yüksek Öğretim, Yaşar Üniversitesi Yayınları.

Sakınç, S. ve Bursalığlu, A. S., (2012). Yükseköğretimde Küresel Bir Değişim: Girişimci Üniversite Modeli. Yükseköğretim ve Bilim Dergisi, 2 (2), s. 92-99.

Sebkova, H., (2002). Accreditation and Quality Assurance in Europe. Higher Education in Europe, 27(3), p.239-247.

Serbest, H. A., (2009, 6-8 Kasım). Mühendislik Eğitim Programları Değerlendirme ve Akreditasyon Derneği, 19. Mühendislik Dekanları Konseyi Toplantısı.

Süngü, H. ve Bayrakcı, M., (2010). Bologna Süreci Sonrası Yükseköğretimde Akreditasyon Çalışmaları. Türk Eğitim Bilimleri Dergisi, 8(4), s. 895-912.

Şenol, E., (t.y.), Aurupa Üniversiteler Birliği (European University Associations-EUA), PowerPoint slaytları, Ankara: Gazi Üniversitesi Tıp Fakültesi.

Vught, F.A. V \& Westerheijden, D. F., (1994). Towards a General Model Of Quality Assesment in Higher Education. Kluwer Academic Publishers, Higher Education 28, Netherlands, p. 355-371.

Yelken, Y.T., Çelikkaleli, Ö. ve Çapri, B. (2007). Eğitim Fakültesi Kalite Standartlarının Belirlenmesine Yönelik Öğretmen Adayı Görüşleri. Mersin Üniversitesi Eğitim Fakültesi Dergisi, 3(2), s. 191-215.

YÖDEK - Yükseköğretim Kurumlarında Akademik Değerlendirme ve Kalite Geliştirme Komisyonu (2007). Yükseköğretim Kurumlarında Akademik Değerlendirme ve Kalite Geliştirme Rehberi, http://adkg.ankara.edu.tr/dosyalar/yodek_rehberi_1_1. pdf, (23.10.2016).
YÖK-Yükseköğretim Kurulu (2014). Yükseköğretimde Kalite İçin, Ankara Üniversitesi Basımevi Müdürlüğü.

YÖK-Yükseköğretim Kurulu (2007). Türkiyénin Yükseköğretim Stratejisi, Yükseköğretim Kurulu, Ankara.

YKK- Yükseköğretim Kalite Kurulu (2016). KIDR Hazırlama Kilavuzu, http://www.yok.gov.tr/documents/23233405/23540205/kurum+i\%C3\%A7\%20de\%C4\%9Ferlendirme+rapor+haz\%C4\%B1rlama+k\%C4\%B1lavuzu. pdf/133cab6f-f0aa-4ee0-ad48-0b0868a883ae (03.12.2016).

http://www.yok.gov.tr/web/uluslararasi-iliskiler/kalite-guvence$\operatorname{si1}(07.07 .2016)$.

http://www.yok.gov.tr/web/uluslararasi-iliskiler/sss (22.10.2016).

www.yodek.org.tr (24.10.2016).

http://www.yok.gov.tr/web/uluslararasi-iliskiler/tyyc-genel (11.10.2016).

http://www.yok.gov.tr/documents/23233405/23540205/ USUL+VE+ESASLAR_tarih.pdf/884573de-9f3a-4989-9847e6ce31776e80 (12.12.2016)

http://www.yok.gov.tr/documents/23233405/23540205/yok+kitapcik+baski.pdf/ce3d7253-affc-487f-a2ee-54e13997fc6b (04.12.2016)

5018 sayllı Kamu Mali Yönetim ve Kontrol Kanunu, 24.12.2013 tarih ve 25326 Sayılı Resmî Gazete.

Türkiye Yeterlilikler Çerçevesinin Uygulanmasına Illişkin Usul ve Esaslar Hakkında Yönetmelik, 19.11.2015 tarih ve 29537 Sayılı Resmî Gazete.

Yükseköğretim Kalite Güvencesi Yönetmeliği, 23.07.2015 tarih ve 29423 Sayılı Resmî Gazete.

Yükseköğretim Kalite Güvencesi Sistemi ve Yükseköğretim Kalite Kurulu, 01.07. 2017 tarih ve 30111 Sayilı Resmî Gazete. 